\title{
Needed Reference Services for American Agriculture'
}

Mr. Moriarty is director of libraries, Purdue University.

$\mathrm{W}$ HEN oN Mar. I5, I948 we at last received the index to volume 95 of the Experiment Station Record for its final year 1946, we put together and sent to the bindery the end volume of one more agricultural reference service. On its return it was put on the shelves with other agricultural reference titles and like them will steadily grow less useful and be superseded as it ages. It is impossible for librarians and others concerned with agricultural information not to consider and mourn somewhat at this steady aging of first aids to data on agriculture. The sections of the usual reference collection where the specific volumes of agriculture are shelved are tending to become shabbier and less frequented. Instructions to new assistants have constantly to reiterate that Bailey is only good up to World War I, and they contain similar cautions about the whole three or four shelves.

Among ourselves it may be worth while to review exactly how old agricultural reference material is as embodied in the usual types of reference books. To start perversely with the Y's, it is apparent we have a yearbook only in name. Henry Wallace repeated his father's warping of the Yearbook of Agriculture. From 1925 when, with the elder Wallace's leaving office, Jar-

\footnotetext{
1 Paper presented at meeting of Agricultural Libraries Section, A.C.R.L., June 18, 1948, Atlantic City, N.J.
}

dine came in, and on up through 1935, there was an annual section, "What's New in Agriculture" in the Yearbook, which together with the annual statistics was quite well indexed, and so served as a good first approach to both date and elementary information on new developments. The present so-called Yearbook is a very fine product, but each issue is, as you know, really a monograph on some one subject of composite authorship and would better be scattered by us among the collection according to the volumes' varying topics than held together as a set as we usually do. Doane's Agricultural Digest can be made to serve as a current yearbook but does not set volume after volume on the shelf to serve as an annual record.

I have already mentioned Liberty Hyde Bailey's Standard Cyclopedia of Horticulture as it is currently known. It started forty years ago as a cyclopedia of American agriculture and even in its latest form it goes back to a copyright between 1914 and 1917. It is still the best and actually almost the only adult encyclopaedic material on general agriculture. Its editor has found it possible only to keep up the material on plants in it, by issuing the volume known as Hortus Second whose latest copyright is 1941. The other encyclopaedic work still on our shelves is the rather juvenile Book of Rural Life whose first readers back in I 925 would find it not so engrossing today. It does, however, take a decidedly wider geographical view than Bailey and very 
occasionally now still gives a good first lead.

A book like Earley V. Wilcox's Modern Farmers' Cyclopedia of Agriculture (c. 1944) is less than five hundred pages and little better than any new elementary general textbook. We have had then no general or universal encyclopaedia in the last generation, and in the case of the encyclopaedia's sister books, the dictionary and the handbook, there are likewise no universal agricultural dictionary old or new of any merit, not any new handbook since the 1926 edition of the Extension Service Handbook on Agriculture and Home Economics by $\mathrm{T}$. W. Harvey, which the U.S.D.A. published.

To make an encyclopaedia or dictionary approach to an agricultural subject these days, a preliminary refinement of the topic has to be undertaken in order that use of some smaller and specialized fields' reference books may be made. Hortus Second just mentioned, and Norman Taylor's or Black's Gardening Dictionaries ( 1936 and I92 I, American and British respectively) must be used. So can Standardized Plant Names by Harlan P. Kelsey and William A. Dayton (Harrisburg, McFarland Co., c. 1942), which has been adopted as the standard for botanical nomenclature by many horticultural organizations.

A check should also include J. H. Vanstone's Raw Materials of Commerce which is in two volumes. Volume one is on Vegetable Products and volume two on Animal, Mineral, and Synthetic Products, but with data back of the year I 929 only. Should the field of query be one in animal husbandry, a book like M. C. Self's The Horseman's Enclyclopaedia (New York, Barnes, I946, 5 I 9 p.) is handily arranged and might help. In any event, however, these last named books are only patches over the chinks in the walls of our tremendous need for agricultural documentation.
When another type of reference book, that dealing with the physical basis of agriculture, is considered what is available is equally old. Our Atlas of American Agriculture is dated 1936 , but this is not a true indication of the age of its contents. A short mention of the project for this atlas deserves attention by persons concerned with agricultural information service. Its original plan back around World War I was brave enough and was to include sections on land relief, climate, soils, and natural vegetation, all of which have in fact been published. It was also planned to have sections on (I ) crops, (2) livestock, (3) size of farms and systems of farming, (4) land utilization and farm tenancy, (5) rural population and organizations. Of these sections none was published except one item from crops, namely "Cotton," in advance sheets in 1918; and one item from rural population and organizations, namely, "Rural Population" in I919. Hardly had these been issued, when a decision was made to hold the publication of data in atlas form strictly to physical conditions which are more or less permanent. These other data of a social and economic nature were used in a series of articles in the Yearbook of Agriculture from I92 I through 1925. Some were published in the Graphic Summary of American Agriculture (Miscellaneous Publication I05, I931).

The reduced program for the Atlas permitted issuance of advance sheets for various sections from 1918 when "Frost and the Growing Season" came out, to the "Soils" section in 1935. Thus a book with a 1936 imprint has data which were then two decades old and are even now the only atlas form presentation of them after still another dozen years.

If this is the story of the physical side of agriculture, what about the human side? It is well known that Who's Who in 
America does not do a satisfactory coverage of rural leaders. Its selection policy, which has the strength and weakness of its type, namely, the mutual admiration society scheme, does not bring in the rural group. Nor does any other current reference book. From 1917 through 1930, L. H. Bailey and his daughter issued four volumes of R.U.S., a biographical register of rural leadership in the United States and Canada (1918, 1920, 1925, 1930) which included almost 7000 names, with fairly full who's who type information. Since 1930, mostly services of a directory nature have been available. One of these is a commercial publication, Directory of Agricultural and Home Economics Leaders (1936, William G. Wilson, eighteenth edition). Recourse for personal records usually has to be to material for more special groups, such as the Forestry Directory by Thomas Gill and E. C. Dowling published by the American Tree Association in 1943 and the various directories of its staff issued by the U.S.D.A.; or Who's Who in the Egg and Poultry Industries, and Who's Who in the Hatchery $W$ orld, and yearbook which for one field gives feast instead of the usual famine.

The U.S.D.A. has likewise worked earnestly in the field of the history of American agriculture. Two excellent numbers of the Bibliographical Contributions issued by U.S.D.A. Library, both by E. E. Edwards, have stressed this field: No. 32 : "References on Agricultural History As a Field for Research" (4I p., 1937) and No. 33: "References on American Colonial Agriculture" (IOI p., I938). But no standard and comprehensive history has been produced. There were issued some years ago by the Carnegie Institution two companion volumes, one by P. W. Bidwell and one by L. C. Gray on the history of agriculture to 1860 in the Northern and Southern
United States respectively (1925, 1933). No successor volumes for the eighty-eight years since or for other regions have come forth and students must be offered very general treatments like N. S. B. Gras' History of Agriculture in Europe and America, done in 1925 , with a single new chapter to cover 1920 to 1940 . The dozen or so popular histories, e.g., R. W. Howard's Two Billion Acre Farm (1945) are, to put it politely, too informal for any serious investigator.

Even in the subsidiary fields histories are too few. It is hard to find documentation for the various states. When you come on an item like U. P. Hedrick's History of Agriculture in the State of New York (1933), it is a big event. When you turn to the various subject fields, there are hardly any volumes such as L. O. Howard's $H$ is. tory of Applied Entomology (1930).

And now we have rambled through the various types of general reference sources or lack of them in the field of agriculture, all that is, except two. These are statistics and bibliography and they should be saved for last. In these types of reference services, American agriculture has had considerable coverage.

The U. S. government, and particularly the U.S.D.A., has labored well in both. In statistics the Census of Agriculture and the annual Agricultural Statistics, which later yearly publishes some 175,000 statistics, should satisfy all but the most unusual breakdowns and often these can be located through the fairly new Census Bureau service called: Census Publications, Catalog and Subject Guide with its supplementary monthly title: Lists of Publications Issued.

With regard to bibliography, the United States has been outstandingly "fortunate. From 1889 to 1945 , the Experiment Station Record currently digested periodicals 
and publications of the United States and other countries relating to agriculture and, of course, the publications of our agricultural experiment stations. In 1945, its was the oldest title in the current bibliography of agriculture in the world. Abstracting between 5000 and 7000 titles annually it was a basic source. Granted that such coverage as such was inadequate, nevertheless, it was treasured, searched, and cited by American agricultural investigators as few other agricultural reference aids. Since I 916 it has been supplemented by the $A$ gricultural Index, listing now always about I 5,000 titles yearly, with no abstracting. Beginning in July 1942, the U.S.D.A. Library started to issue its monthly Bibliography of Agriculture, listing titles, without abstracts, but with translations of titles for foreign articles and with curt phrases of explanation when titles are ambiguous. These are helpful in discriminating among articles. The great significance of the Bibliography of Agriculture is its coverage, now running to some 80,000 titles annually.

This figure deserves a certain awe and more meditation. Actually, it offers some explanation for the situation in the field of agriculture with regard to reference books. If the field requires 80,000 periodical references annually to describe it, any encyclopaedist would have to be a Diderot for fair to encompass it. But the 80,000 articles, of course, represent a world coverage and possibly, you say, an American survey might be accomplished. Actually this does not make sense either, for American agriculture is almost inconceivably dynamic and international. Let me illustrate this by the story of Victoria. Although not a movie queen, nevertheless like a star, Victoria soared to fame, and made fortunes and then as quickly fell into nothingness. Victoria is a brand of oats. The Ames, Iowa, Station was where Victoria was groomed by Drs. H. C. Murphy, T. R. Stanton, and others. These men were testing to find varieties or strains of oats that would resist grain diseases, smuts, and rusts (crown, stem, etc.). In Victoria, which came from Argentina, they found an oat extremely resistant to them. They also, however, found it weak in its straw and in certain other respects. By extensive genetic work, Victoria was not only given strong straw, but increased yields and even stronger disease resistance.

Before Victoria, in 1941, our farmers lost 40 per cent of their crops to rust, especially crown. Came Victoria and all this was a thing of the past. When 1945 plantings were checked, Victoria varieties were on 98 per cent of Iowa's oat acreage and on 75 per cent of the rest of the United States'. In three years, with less disease and more oats, Iowa farmers were $\$ 70,000,000$ and more ahead.

Already, however, with 1944 harvests, a once minor oat blight, named Helminthosporium, came along and it particularly thrived on Victoria strains of oats causing them to be abandoned as quickly as they were once adopted. Helminthosporium was an old blight to which most oats sown in the United States had-resistance, but not Victoria, a foreigner, and her scientific sponsors had not checked on this. They may be able to do something but it probably will not matter because new varieties like Clinton and Bond are taking over.

But this is certainly not the end of the story on oat breeding and defeats and victories will continually need recording.

It probably will not be recorded in encyclopaedias or even in dictionaries. All books, even ordinary textbooks, take one year to get to publication and reference books, if they are to be of good quality, take longer. Agriculture, which includes at least soils and their management, horticulture, 
animal husbandry, and farm economics, is progressive in almost all its aspects and inescapably world wide. In both tempo and scope, it has become an implacable enemy of reference books.

This does not mean an end of agricultural reference books, but it does mean specialized and modest ones. It also means that an increased load must be placed on another element of our service. Old Varro, the Roman agricultural authority, divided the instruments of agriculture into the mute and the articulate. If he lacked a plow, or any mute instrument, I'm sure he would have had the digging done by the hands of his aritculate slaves. So today with the steady failing of organization in our research documentation, we must pass from hope of help in printed guides, to our reference and other librarians who as best they can must find what print exists to apply to our readers' problems. This, however, is a whole new subject and needs a paper at next year's meeting.

\section{Nonbook Materials in a Teachers College Library}

\section{(Continued from page 315)}

who are taught the use of various types of equipment, are to gain a knowledge of desirable equipment available on the market.

In conclusion, I should like to say that probably the outstanding characteristic of our modern civilization is the rapidity at which change takes place. As Dean Ralph Noyer of our college pointed out recently, there are students now enrolled in teachers colleges who will live to witness the beginning of the twenty-first century, barring atomic destruction or other catastrophe of equal magnitude. If the rate of change in all aspects of living is accelerated proportionately to that which we have experienced during the first half of the present century, these persons and those who follow must accept frequent and sudden adjustment as part of the usual pattern of living to an ever increasing degree. The implications of this prospect for education are clear. Preparation for living and working effectively and for meeting the problems of a civilization in a persistent state of flux will require every resource at our disposal if cultural degeneration is to be avoided.

Teachers must be among the best informed and the best prepared vanguard in the vital struggle with circumstantial forces. A knowledge of and the ability to use intelligently every existing form of communication and teaching aid are essential parts of their equipment. The library in a teachers college which does not provide the needs of its constituency must necessarily become relegated to that class of agency which first assumes a role of minor importance and eventually passes into oblivion. 